\title{
Endring av helsevaner - for helsens skyld eller for å gå ned i vekt?
}

\author{
Rapporterte forsøk på endring av helsevaner hos 40-42 åringer i \\ Buskerud fylke 1996
}

\author{
Bjørg Berge Skåra og Sidsel Graff-Iversen \\ Statens helseundersøkelser, Postboks 8155 Dep, 0033 Oslo \\ Korrespondanse til Bjørg Berge Skåra, telefon 22207655 telefax 22201673 E-post opplshus@online.no
}

\begin{abstract}
SAMMENDRAG
Denne tverrsnittsundersøkelsen viste en klar positiv sammenheng mellom forsøk på å endre spise- og trimvaner og kroppsmasseindeks. Serumkolesterol viste en svak positiv sammenheng med forsøk på å spise sunnere, men det var ingen konsistent sammenheng for gitt nivå av kroppsmasseindeks. Det var heller ingen signifikant sammenheng mellom serumkolesterol og forsøk på endring av mosjonsvaner etter justering for andre variable. Flere kvinner enn menn oppga at de har forsøkt å endre helsevaner til det bedre både når det gjelder kosthold og fysisk aktivitet. Personer som hadde forsøkt å endre spise- og/eller trimvaner, oppgav hyppigere at de ikke brukte fett på brød eller brukte lettmargarin enn de som ikke hadde gjort slike forsøk. De oppgav også i større grad at de drev hard fysisk aktivitet i fritiden. Denne undersøkelsen tyder på at overvekt er en sterkt motiverende faktor for det å forsøke å spise sunnere og trimme mer, og velge gunstigere levevaner.
\end{abstract}

\section{Skåra BB, Graff-Iversen S. Changing health habits - to improve health or to loose weight? Reported efforts of 40-42-years-old in Buskerud county, Norway, to change health habits in 1996. Nor J Epidemiol 1997; 7 (2): 267-271.}

\section{ENGLISH SUMMARY}

Based on data from the cardiovascular screening programme performed by the National Health Screening Service in Buskerud County 1996, the participants' effort of changing their health habits are described. The data show clear associations between effort of changing habits of diet and exercise, and body mass index. Serum cholesterol showed a weak correlation with attempt to change habits of diet, however, there was no consistent correlation for a given level of body mass index. There was no significant association between level of serum cholesterol and effort to change habits of exercise after adjusting for other variables. More women than men said they had tried to improve their habits of diet and exercise. Persons who had tried to change habits of diet and exercise, more frequently chose more healthy alternatives of fat on bread, and participated in harder physical exercise in their spare time. This survey indicates that overweight is a motivation for improving habits of diet and exercise.

40-åringsundersøkelsene i Buskerud kom i gang i 1993 i regi av Statens helseundersøkelser (SHUS) og kommunehelsetjenesten. Alle kommuner har deltatt i undersøkelsen både i 1993 og -96. Hensikten er å kartlegge nivået av riskofaktorer, følge utviklingen over tid, samt legge forholdene til rette for å redusere risiko for framtidig hjerte-karsykdom hos 40-42 åringene. Undersøkelsene ledsages gjerne av oppmerksomhet i lokalmiljøet og skaper muligheter for å påvirke en større gruppe av befolkningen enn bare de undersøkte
(1). I denne artikkelen ser vi på i hvilken grad 40-42åringer som deltok ved helseundersøkelsen i 1996, har forsøkt å endre helsevaner de siste 12 måneder, og hvilke faktorer som er relatert til forsøket på endring.

\section{MATERIALE OG METODE}

Metodene som Statens helseundersøkelser anvender i hjerte-karundersøkelsene er beskrevet av Bjartveit og medarbeidere (2). Data fra sluttrapport fra helseunder- 
søkelsene i Buskerud i 1996 ligger til grunn for de beregninger som blir presentert i denne artikkelen $(3,4)$. I 1996 deltok 2956 menn og 3397 kvinner.

Spørsmålene om forsøk på endring av helsevaner hadde formuleringene: Har du de siste 12 måneder forsøkt å spise sunnere? trimme mer? og slutte å røyke? Det siste besvares bare av røykere.

I undersøkelsen inngår målinger av serum totalkolesterol (mmol/l), høyde (m) og vekt $(\mathrm{kg})$. Kroppsmasseindeks er vekt i forhold til kvadratet av høyden $\left(\mathrm{kg} / \mathrm{m}^{2}\right)$. De ulike nivåene av kroppsmasseindeks er valgt ut fra referanseverdier for kvinner, nivåer for menn er vanligvis noe høyere. Gjennomsnittshøyde for kvinner i Buskerud er 1,66 m. Dersom nivå for kroppsmasseindeksen er $30 \mathrm{~kg} / \mathrm{m}^{2}$ vil det si at kroppsvekten er $82,7 \mathrm{~kg}$. For kvinner og menn definerer vi dette som overvekt.

Type fett i kostholdet hadde fire svaralternativer: Meierismør/hard margarin/smør og margarinblanding, myk margarin, lettmargarin og bruker ikke smør/ margarin på brødet.

Hard fysisk aktivitet (svett/andpusten) i timer pr. uke hadde fire svaralternativer: ingen, under 1, 1-2 og 3 og mer. Den høyeste utdanning fullført hadde fem svaralternativer: grunnskole 7-10 år, realskole/1-2 årig videregående, artium og høgskole/universitet mindre eller mer enn fire år. Røyking sammenfatter sigaretter, sigarer eller pipe daglig. Buskerud er sammenlignet med de 8 andre fylkene som har gjennomført undersøkelser fortløpende siden 1994: Nordland (1994), Rogaland (1994), Aust-Agder (1995), Sør-Trøndelag (1995), Telemark (1995), Sogn og Fjordane (1995), Møre og Romsdal (1996) og Vest-Agder (1996).

Det er kjørt logistiske regresjoner med endringsfors $ø \mathrm{k}(0=$ nei, $1=\mathrm{ja})$ som avhengige variable og et sett uavhengige variable som a priori ble ansett som relevante.

\section{RESULTATER}

Andelen som har forsøkt å endre helsevaner er frapperende lik i Buskerud og de 8 andre fylkene (tabell 1). Kvinner har forsøkt å endre kost- og mosjonsvaner i høyere grad enn menn. Andelen av røykerne som har forsøkt å slutte er ganske lik for kvinner og menn og også mellom Buskerud og de 8 fylkene. Mosjonsvanene har vært forsøkt endret i større grad enn kostvanene.

Tabell 1. Andel (\%) som har forsøkt å endre helsevaner siste 12 måneder*.

\begin{tabular}{|c|c|c|c|c|c|}
\hline \multicolumn{2}{|l|}{ Fylke/år } & \multicolumn{2}{|c|}{$\begin{array}{c}\text { Spise } \\
\text { sunnere }\end{array}$} & $\begin{array}{c}\text { Trimme } \\
\text { mer** }\end{array}$ & $\begin{array}{l}\text { Røyke- } \\
\text { slutt** }\end{array}$ \\
\hline & & \multicolumn{4}{|c|}{ Menn } \\
\hline Buskerud & 1996 & 34 & & 38 & 29 \\
\hline \multirow[t]{2}{*}{8 fylker } & 1994-96 & 34 & & 38 & 30 \\
\hline & & \multicolumn{4}{|c|}{ Kvinner } \\
\hline Buskerud & 1996 & 49 & & 54 & 31 \\
\hline 8 fylker & 1994-96 & 49 & & 54 & 29 \\
\hline $\begin{array}{l}\text { * Buskeru } \\
8 \text { fylker: }\end{array}$ & $\begin{array}{l}\text { d: Menn } \\
: \quad \text { Menn }\end{array}$ & $\begin{array}{l}956 \\
1848\end{array}$ & & $\begin{array}{l}\text { nner } \mathrm{n}=3 \\
\text { nner } \mathrm{n}=3\end{array}$ & \\
\hline
\end{tabular}

Undersøkelsen viser at flere har forsøkt å spise sunnere ved stigende nivå av totalkolesterol, men sammenhengen sto ikke fram som statistisk signifikant i logistisk regresjonsanalyse (tabell 2). Sammenhengen mellom forsøk på å trimme mer og totalkolesterol er ikke konsistent hos de to kjønn.

Det er en klar sammenheng mellom kroppsmasseindeks og forsøk på endring $\mathrm{i}$ helsevaner (tabell 3). Dess høyere kroppsmasseindeks dess høyere hyppighet av endringsforsøk. Dette gjelder både kost- og mosjonsvaner, men gradienten er brattest for kost.

Tabell 2. Andel (\%) som har forsøkt å spise sunnere og/eller trimme mer siste 12 måneder etter totalkolesterol.

\begin{tabular}{|c|c|c|c|c|c|c|}
\hline \multirow{2}{*}{$\begin{array}{l}\text { Totalkolesterol } \\
\mathrm{mmol} / \mathrm{l}\end{array}$} & \multicolumn{3}{|c|}{ Menn } & \multicolumn{3}{|c|}{ Kvinner } \\
\hline & $\mathrm{n}$ & Spise sunnere & Trimme mer & $\mathrm{n}$ & Spise sunnere & Trimme mer \\
\hline$<4,5$ & 385 & 31 & 40 & 744 & 44 & 52 \\
\hline $4,5 \_5,9$ & 1627 & 33 & 38 & 2059 & 49 & 54 \\
\hline $6+$ & 939 & 36 & 37 & 501 & 51 & 56 \\
\hline
\end{tabular}

Tabell 3. Andel (\%) som har forsøkt å endre helsevaner siste 12 måneder etter kroppsmasseindeks.

\begin{tabular}{lccccccc}
\hline Kroppsmasse- & \multicolumn{3}{c}{ Menn } & & \multicolumn{3}{c}{ Kvinner } \\
\cline { 2 - 4 } \cline { 6 - 7 } indeks $\left(\mathrm{kg} / \mathrm{m}^{2}\right)$ & $\mathrm{n}$ & Spise sunnere & Trimme mer & & $\mathrm{n}$ & Spise sunnere & Trimme mer \\
\hline$<25$ & 1044 & 25 & 34 & & 2006 & 40 & 49 \\
$25-29,9$ & 1556 & 37 & 39 & & 1049 & 58 & 59 \\
$30+$ & 348 & 48 & 44 & & 334 & 72 & 62 \\
\hline
\end{tabular}


Figurene 1 og 2 viser hvor stor andel som har forsøkt å spise sunnere siste 12 måneder etter kroppsmasseindeks og totalkolesterol. For alle tre nivåer av totalkolesterol stiger andelen som har forsøkt å spise sunnere med stigende kroppsmasseindeks. På den andre side er det ingen konsistent sammenheng mellom forsøk på å spise sunnere og totalkolesterol for gitt nivå av kroppsmasseindeks.

Figurene 3 og 4 gir hyppigheten av forsøk på å trimme mer etter kroppsmasseindeks og totalkolesterol. For menn øker hyppigheten av forsøk med økende kroppsmasseindeks for alle nivåer av totalkolesterol. For kvinner øker hyppigheten med økende kroppsmasseindeks først og fremt blant dem som har totalkolesterol under $5 \mathrm{mmol} / \mathrm{l}$.

Figur 5 viser andel menn og kvinner som har forsøkt å spise sunnere etter valg av type fett på brødet. Det er flere som har forsøkt å spise sunnere siste 12 måneder blant dem som enten bruker lettmargarin eller ikke fett på brødet, enn blant dem som bruker smør eller hardmargarin. Populært kan man si at hyppigheten av forsøk på sunnere kost avtar jo mer ugunstig valget av fett er i kostholdet. Eller at de som forsøker å endre helsevaner også gjør et bedre valg av type fett.

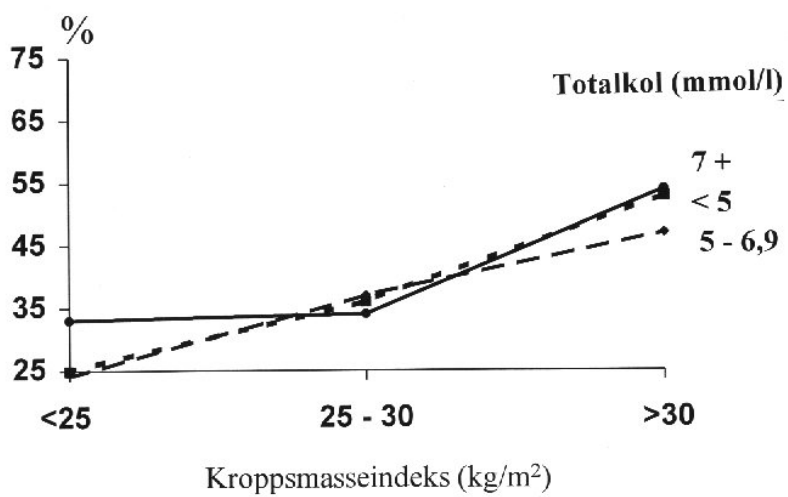

Figur 1. Andel (\%) menn som har forsøkt å endre helsevaner siste 12 måneder etter kroppsmasseindeks.

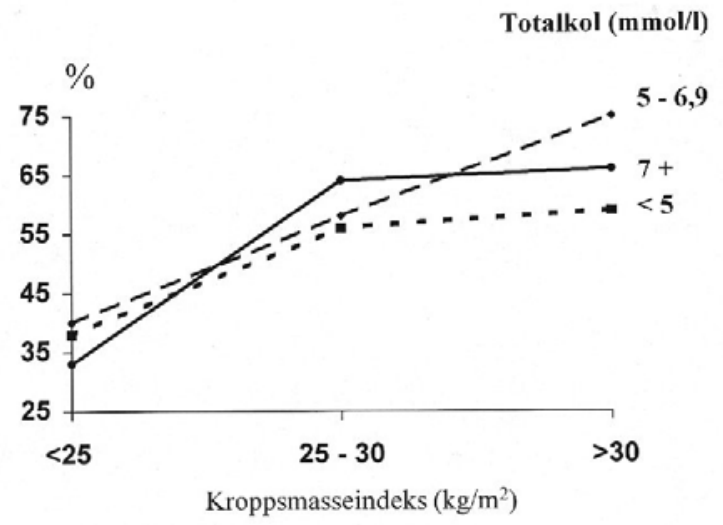

Figur 2. Andel (\%) kvinner som har forsøkt å spise sunnere siste 12 måneder etter kroppsmasseindeks.
Figur 6 viser andel menn og kvinner som har forsøkt å trimme mer etter nivå av hard fysisk aktivitet. Det er høyere andel som har forsøkt å trimme mer blant dem som har hard fysisk aktivitet.

I logistiske regresjoner kom disse variable ut som statistisk signifikante, med forsøk på endringer i både kost og mosjon som avhengige variable: kjønn, kroppsmasseindeks, hard fysisk aktivitet, margarin (både hard og myk relativt til ikke fett på brødet) (tabell 4). Utdanning var signifikant med mosjon som avhengig, mens røyking var signifikant med kost som avhengig variabel.

\section{DISKUSJON}

Denne tverrsnittsundersøkelsen viste en klar sammenheng mellom forsøk på å endre kost- og trimvaner og kroppsmasseindeks. Serumkolesterol viste en svak positiv sammenheng med forsøk på å spise sunnere, men det var ingen konsistent sammenheng for gitt nivå av kroppsmasseindeks. Det var heller ingen signifikant sammenheng mellom serumkolesterol og forsøk på endring av mosjonsvaner etter justering for andre variable.

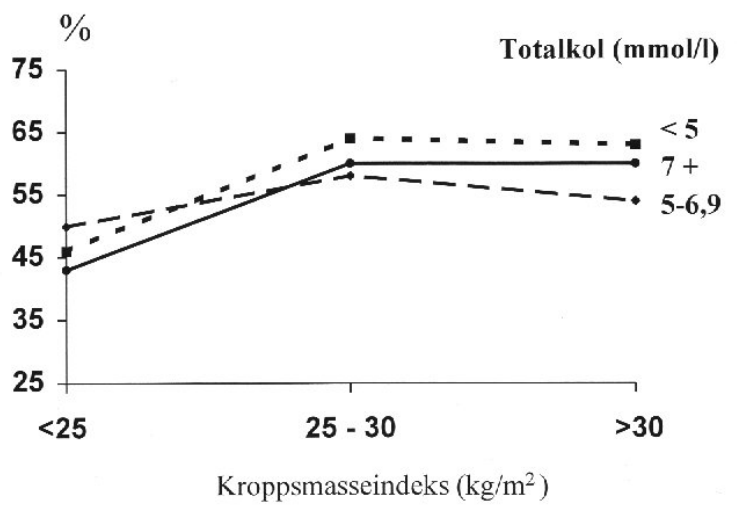

Figur 3. Andel (\%) menn som har forsøkt å trimme mer siste 12 måneder etter kroppsmasseindeks.

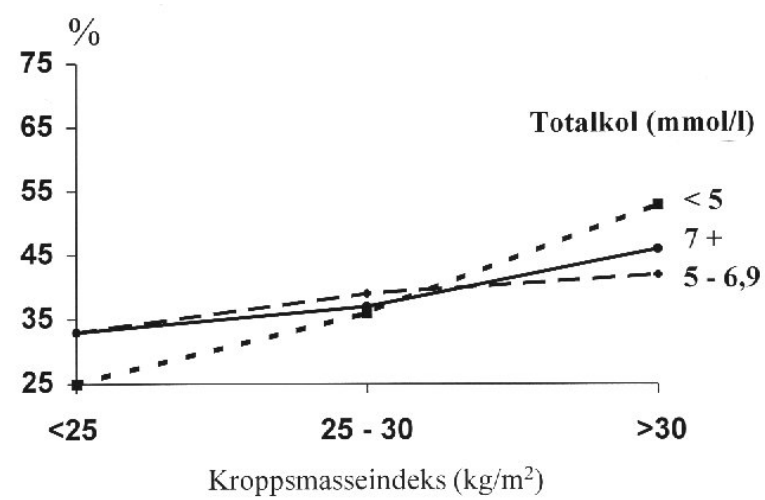

Figur 4. Andel (\%) kvinner som har forsøkt å trimme mer siste 12 måneder etter kroppsmasseindeks. 


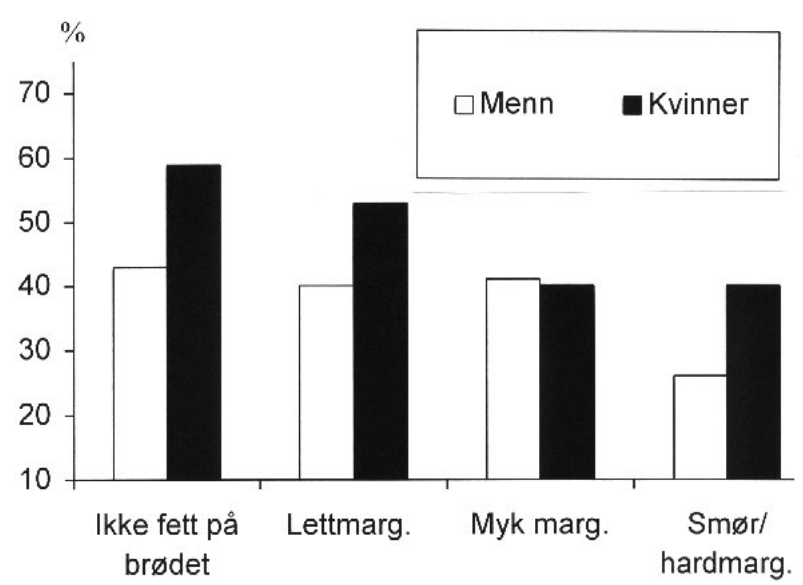

Figur 5. Andel (\%) som har forsøkt å spise sunnere siste 12 måneder etter type fett på brødet.

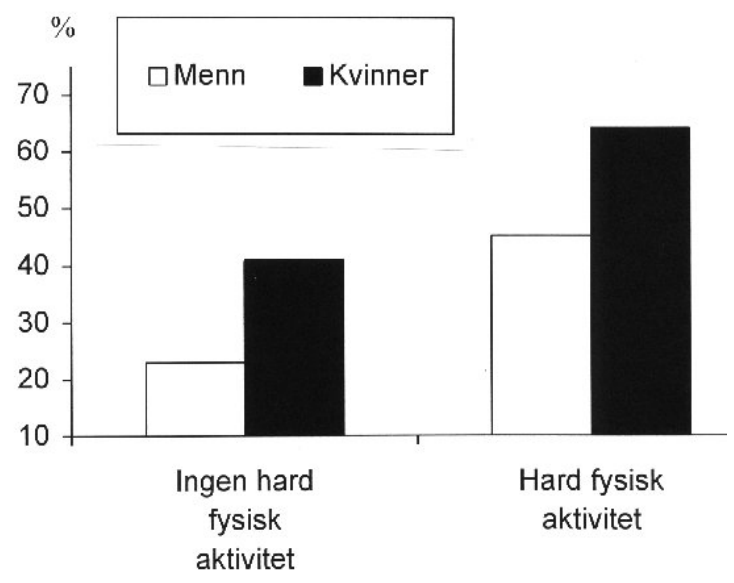

Figur 6. Andel (\%) som har forsøkt å trimme mer siste 12 måneder etter hard fysisk aktivitet ( $\mathrm{ja} / \mathrm{nei})$.

Tabell 4. Logistiske regresjonsmodeller med forsøk på å spise sunnere og forsøk på å trimme mer som avhengige variable.

\begin{tabular}{|c|c|c|c|c|c|c|}
\hline \multirow[b]{3}{*}{ Variabel } & \multicolumn{6}{|c|}{ Avhengig variabel $(0=$ nei, $1=$ ja $)$} \\
\hline & \multicolumn{3}{|c|}{ Forsøk på å spise sunnere } & \multicolumn{3}{|c|}{ Forsøk på å trimme mer } \\
\hline & Koeff. & SE & $\mathrm{p}$ & Koeff. & SE & $\mathrm{p}$ \\
\hline $\operatorname{Kjønn}(0=$ kvinne, $1=$ mann $)$ &,- 7984 & 0604 & 00 &,- 8274 & 0595 & 00 \\
\hline BMI $\left(\mathrm{kg} / \mathrm{m}^{2}\right)$ & 1,1886 & 0841 &, 00 &, 6344 &, 0802 &, 00 \\
\hline Totalkolesterol (mmol/l) &, 0431 & 0282 & 13 &, 0083 & 0279 &, 76 \\
\hline Systolisk bt (mm) &,- 0041 & 0021 &, 05 &,- 0021 & 0020 &, 30 \\
\hline $\operatorname{Røyker}(0=$ nei, $1=$ ja $)$ &,- 1892 &, 0590 &, 00 &,- 0863 & 0580 &, 14 \\
\hline $\begin{array}{l}\text { Utdanning }(1=\text { grunnskole, } \\
2,3,4,5=\text { universitet } 4+\stackrel{a}{ })\end{array}$ & ,0293 & 0217 &, 18 &, 0869 & 0214 &, 00 \\
\hline $\begin{array}{l}\text { Margarin }(0=\text { ikke fett, } 1=\text { smør, } \\
\text { hard marg eller bland. })\end{array}$ &,- 5964 & 0884 &, 00 &,- 3875 & 0869 &, 00 \\
\hline $\begin{array}{l}\text { Myk marg. }(0=\text { ikke fett, } 1=\text { bløt } \\
\text { marg. })\end{array}$ &,- 5028 & ,0799 &, 00 &,- 3246 & 0793 &, 00 \\
\hline $\begin{array}{l}\text { Lettmarg. }(0=\text { ikke fett, } \\
1=\text { lettmarg. })\end{array}$ &,- 1046 &, 0743 &, 16 &,- 0814 &, 0747 & ,29 \\
\hline $\begin{array}{l}\text { Hard fys.akt. }(1=0 \text { timer/uke, } \\
2,3,4=3+\text { timer/uke })\end{array}$ &, 1241 & ,0260 &, 00 & ,3683 &, 0260 &, 00 \\
\hline
\end{tabular}

Flere kvinner enn menn oppga at de har forsøkt å endre helsevaner til det bedre både når det gjelder kosthold og fysisk aktivitet.

Vi vet ikke i hvilken grad sammenhengen mellom kroppsmasseindeks og forsøk på å endre helsevaner avspeiler mange og seriøse forsøk eller i hvilken grad personen føler at han eller hun burde endre vaner. Det at undersøkelsen ikke er anonym og at skjemaet leveres til en sykepleier ved frammøte kan trekke deltakernes svar i retning av å svare slik de tror det er forventet.

Det er ofte fokus på vekt og slanking i media og den slanke linje er en trend i tiden. Kroppsmasseindeksen har økt for menn med $0,9 \mathrm{~kg} / \mathrm{m}^{2}$ og avtatt med 0,3 $\mathrm{kg} / \mathrm{m}^{2}$ for kvinner over en periode på 25 år (5). Budskapet fra helsepersonell har vært at magrere kost og mer fysisk aktivitet skal gi lavere risiko for hjerte/karsykdommer og kreft. Det er den samme magre kosten og økt fysisk aktivitet som lanseres som løsning for å beholde den slanke linje (Jfr. Statens Ernæringsråds/ NRKs kampanje for slanking: Tips om slanking og god mat/-97).

Det er de som har en høyere kroppsmasseindeks, og særlig kvinner, som i størst utstrekning har forsøkt å endre kosthold og aktivitetsnivå. Ser vi på hvordan kvinnene rapporterer bruk av type fett på brødet, finner vi at jo høyere korppsmasseindeksen er, jo magrere alternativ blir valgt (data ikke vist). Det tyder på at de 
har kunnskapen om hvilke valg de bør gjøre i kostholdet sitt og at de har en bevissthet om at endringer $i$ kosthold og fysisk aktivitet kan bidra til vektkontroll.

Den svake sammenhengen mellom totalkolesterol og forsøk på endring i helsevaner kan skyldes at folk ikke har kjennskap til sitt kolesterolnivå. Imidlertid svarer 50\% av MMI's telefonomnibus utvalg i en nyere spørreundersøkelse, at de er meget godt eller godt kjent med sitt kolesterolnivå.

I dette materialet er det drøyt en tredjedel som røyker daglig og en fjerdedel av disse har forsøkt å slutte. Det er vist at eksrøykere har den høyeste kroppsmasseindeks etterfulgt av aldri-røykere, mens røykere har den laveste kroppsmasseindeks i gjennomsnitt (5). Frykten for å gå opp i vekt ved røykeslutt kan derfor være begrunnet.

Det kan være ulik begrunnelse for forsøk på å endre helsevaner hos friske folk. En tradisjonell fokusering på risikofaktorer for sykdom i argumentasjonen for endring kan være en for ensidig og negativ måte å forholde seg til helse på. Det er livet i dag og den nære framtid som er viktigst for mange. En nærliggende motivasjonsfaktor for friske førtiåringer er å være slank. Undersøkelser har vist at folks forhold til kosthold og alkoholforbruk styres mest av hensynet til vekt og sosial status, ikke så mye av hensyn til helse $(6,7)$. Det kan derfor være formålstjenlig med et skifte i fokusering fra risikofaktorer alene til å anerkjenne og gi oppmerksomhet til førtiåringer sine helseressurser (8). Det er i første rekke viktig å vekke nysgjerrighet og interesse for deretter å motivere. I forbindelse med selve atferdsendringen er det særlig viktig å belønne og gi sosial støtte (9).

Denne undersøkelsen tyder på at overvekt er en sterkt motiverende faktor for det å forsøke å spise sunnere og trimme mer. Forsøkene er også knyttet opp til valget av en bedre type fett $\mathrm{i}$ kostholdet og hardere fysisk aktivitet. Mulighet til mobilisering av interesse og motivasjon til endring hos førtiåringene bør kunne utnyttes i forebyggende folkehelsearbeid til å oppnå atferdsendring som også bidrar til å bedre folks helse.

\section{LITTERATUR}

1. Hewitt S, Sandvig A, Wøien G, Graff-Iversen S. Utvikling av risikofaktorer for hjerte-karsykdommer hos 4042-åringer i Finnmark fylke 1973-93. Tidsskr Nor Lageforen 1995; 115 (30): 3719-23.

2. Bjartveit K, Stensvold I, Lund-Larsen PG, Gjervig T, Krüger Ø, Urdal P. Hjerte- og karundersøkelser i norske fylker. Tidsskr Nor Logeforen 1991; 111 (17): 2063-72.

3. Wøien G. Hjertesaken. Rapport om hjerte-karundersøkelsen i Buskerud. Statens helseundersøkelser, 1996.

4. Bjartveit K, Wøien G. Risikofaktorer for hjerte-karsykdommer i Norge. Resultater fra undersøkelser i 18 fylker. Oslo: Statens helseundersøkelser, 1997.

5. Tverdal A. Høyde, vekt og kroppsmasseindeks for menn og kvinner i alderen 40-42 år. Tidsskr Nor Lageforen 1996; 116 (18): 2152-6.

6. Jacobsen ET. Hvorfor gør folk ikke, som vi siger? Sundt og Sosialt. Komiteen for Sundhedsoplysning 4, 1995; 4-6.

7. Jørgensen LM, Sørensen TIA, Larsen S. Kostfaktorers indflydelse på vægtændringer vurdert ved hjælp af multivariate grafiske modeller. Ugeskr Laeger 1997; 159 (10): 1443-47.

8. Hollnagel H, Malterud K. Shifting attention from objective risk factors to patients' self-assessed health resourses. A clinical model for general practice. Fam Pract 1995; 12: 423-9.

9. Prochaska JO. What causes people to change from unhealthy to health enhancing behaviour? I: Heller T, Bailey L, Pattison S, red. Preventing cancers. Buckingham, England: Open University Press, 1992. 